\title{
AKTUALISASI INDONESIA DALAM G20: PELUANG ATAU TREN?
}

\author{
Sukma Sushanti \\ Program Studi Hubungan Internasional \\ Fakultas Ilmu Sosial dan Ilmu Politik, Universitas Udayana \\ Email : sukmasushanti@gmail.com
}

\begin{abstract}
ABSTRAK
Bermula dari sebuah pemikiran untuk menyelesaikan krisis keuangan global, dan diperlukannya sebuah penguatan internasional yang berasal dari komitmen negara-negara yang mempunyai skala ekonomi terbesar, eksistensi G20 menjadi sebuah harapan baru bagi pertumbuhan ekonomi dunia. Klub ekonomi eksklusif ini hadir untuk memberikan sebuah kerangka global, yang kemudian diinfiltrasikan ke berbagai institusi internasional ataupun mekanisme kerjasama ekonomi. Banyak negara yang memberikan pengharapan pada komunitas ekonomi eksklusif ini melalui keterwakilan anggota aktif dalam kelompok ini. Tidak terlepas pula mandate yang melekat pada Indonesia sejak ditetapkannya sebagai anggota tetap G20. Indonesia menjadi vital point bagi negara-negara berkembang untuk menyuarakan kepentingan mereka, terutama terkait dengan perimbangan kekuasaan pada konteks perdagangan internasional. Jika Indonesia dapat memainkan perannya secara baik dalam G20, maka capaian kepentingan nasional negara dapat terakses dengan baik tanpa mengesampingkan tuntutan moral secara regional ataupun global. Kritik muncul ketika peran Indonesia dinilai hanya sebagai bandwagoning terhadap negara-negara besar, tanpa mempertimbangkan sebuah kalkulasi rasional yang mumpuni bagi kepentingan nasionalnya.
\end{abstract}

Kata kunci: skala ekonomi terbesar, perimbangan kekuasaan, kepentingan nasional. bandwagoning, kalkulasi rasional

\begin{abstract}
Starting with the idea to build mechanism in resolving global financial crisis, in which need international commitment from the countries with the largest economy scale to strengthening the international governance, the existence of G20 lead to the new hope for the future of the world economy. This exclusive economy club emerge to create global framework then infiltrating vary recommendations into various international economy institution, also cooperation mechanism, both in regional and international scale. The states rely their hope on this club through the active member states representative in G20. Thus, Indonesia has a mandate to voice the interest of developing countries since inaugurated as the permanent member of G20. Indonesia become a vital point of the interest from the developing countries, in the context to balance the power in international trade system. If Indonesia able to play as the important actor in G20, then its national interest will achieve smoothly, without neglecting the moral demand in regional or global scale. The critics arise when people start to see the role of Indonesia is only as bandwagon state of the developed countries rather than being rational to calculate the achievement of the national interest in G20.
\end{abstract}

Keywords: global financial crisis, largest economy scale, developing countries, national interest, bandwagon state 


\section{PENDAHULUAN}

Implikasi dari terbentuknya G20 semakin kuat di tahun 2008, terlebih ketika forum ini mengalami transisi level pertemuannya menjadi wadah bertemunya para kepala negara yang duduk bersama guna menyikapi kondisi perekonomian dunia. Proyeksi masa depan dengan dibentuknya G20 adalah untuk mengantisipasi krisis ekonomi dunia, karena forum ini mempunyai tujuan utama yaitu membangun komitmen internasional yang akan memberikan peran nyata dalam memberikan solusi global bagi setiap permasalahan ekonomi. Esensi common goal yang menjadi landasan vital dari forum ini adalah terbentuknya sebuah aksi kolektif dalam menyikapi problematika ekonomi dunia, dengan mengedepankan fleksibilitas. Selain itu G20 dijadikan acuan bagi pengambilan kebijakan ekonomi dunia, dan juga sebagai pedoman penting bagi forum multilateral (WTO) lain untuk memberikan respon terkait situasi ekonomi dunia. Reformasi dalam badan-badan ekonomi dunia seperti International Monetary Fund (IMF), World Bank, bahkan World Trade Organization (WTO) banyak dikontribusikan dari hasil-hasil pertemuan forum G20. Pengaruh besar dari eksistensi G20 membuat para kepala negara dari para anggota permanen forum ini bersepakat untuk menjadikannya sebagai premier forum for Economic Cooperation (forum utama kerjasama ekonomi) (Hermawan dkk, 2011). Melihat begitu besar dan luasnya skala cakupan kerjasama, serta implikasi kuat dari G20, maka menjadi wajar banyak negara menawarkan dirinya untuk dapat dikukuh menjadi anggota permanen dari klub ekonomi eksklusif ini. Ditambah dengan cakupan isu yang akan menjadi perhatian forum ini adalah hal-hal yang tidak hanya berkaitan dengan ekonomi, namun juga akan menyinggung isu sosial dan lingkungan. Merujuk pada ambisi kuat dari forum ini memberikan stimulus pada jumlah negara yang ingin terlibat secara aktif di G20. Indonesia menjadi salah satu negara yang justru diberikan peluang untuk menjadi anggota permanen dari forum G20.

Ditetapkannya Indonesia sebagai anggota tetap dari forum G20 berdasarkan dengan beberapa hal penting, yang pertama adalah perannya dalam menginisiasi pembentukan ASEAN. Pementukan ASEAN yang mencakup sebagai jembatan 
dalam mewadahi persoalan-persoalan ekonomi kawasan. Pengalaman yang telah dimiliki oleh Indonesia tersebut memberikan peluang baginya untuk diikutsertakan dalam klub ekonomi eksklusif ini. Selain itu pengalaman Indonesia dalam mengatasi krisis keuangan pada tahun 1998 yang dinilai cukup baik, dan partisipasi nyata dari Indonesia dalam setiap forum ekonomi dunia. Dan Indonesia pun menjadi salah satu negara di kawasan yang mempunyai skala besar dalam perdagangan dunia. Sebagai satu-satunya negara di kawasan yang menjadi anggota G20, memberikan sebuah harapan baru untuk menyuarakan kepentingan negaranegara ASEAN lainnya dan juga negara berkembang lainnya. Banyak pihak yang menaruh harapannya melalui keterwakilan Indonesia dalam forum ini. Hal penting yang menjadi harapan baru bagi banyak negara berkembang adalah keterbukaan akses pasar dunia untuk komoditas yang dihasilkan, jika selama ini terkendala oleh kebijakan proteksi yang diterapkan oleh Eropa, Amerika Serikat, dan negara-negara besar dunia lainnya.

Distorsi perdagangan dunia yang selama ini menjadi problematika, terutama terkait dengan transparansi mekanisme dari subsidi yang dilakukan oleh banyak negara, telah memberikan hambatan nyata bagi arus perdagangan komoditas dari negara-negara berkembang. Di waktu yang bersamaan WTO sebagai pemegang kendali dari tata kelola perdagangan dunia seringkali mengalami jalan buntu dalam menengahi sengketa perdagangan. Banyak pihak menilai, bahwa WTO pun tidak independen dalam berperan dan justru lebih dominan memainkan standar ganda dalam eksistensinya. Lembaga moneter dunia (IMF) pun banyak dikritisi telah banyak berkontribusi pada keterpurukan kondisi di negara-negara berkembang. Banyak pihak yang memberikan kiritik terhadap dominasi dari beberapa negara besar dalam lembaga dengan mekanisme voting yang dilakukan dalam mengalokasikan dana bantuan kepada negara penerima donor, bahwa semua bantuan akan kembali lagi pada kepentingan negara-negara donor semata (Nowzad, 1981). Hal-hal ini menghadirkan tantangan yang pelik bagi kemampuan dari forum G20 untuk bisa menyelesaikan isyu-isyu ekonomi dunia tersebut. Sehingga, Indonesia pun sebagai anggota dari forum tersebut dituntut bisa berpartisipasi secara aktif dalam menjembatani persoalan-persoalan tersebut. 


\section{OPTIMISME KEANGGOTAAN INDONESIA DI G20}

Keterbukaan secara ekonomi adalah sebuah keniscayaan yang tidak dapat dihindarkan, terlebih di era globalisasi maka interaksi yang berkelindan antara aktor semakin intensif didukung dengan kontribusi inovasi teknologi informasi. Indonesia sebagai aktor negara yang turut aktif dalam memanfaatkan momentum ini sebaik mungkin, salah satunya dengan berperan dalam berbagai forum multilateral, khususnya terkait dengan isyu-isyu ekonomi. Sebagai salah satu elemen hard power yang esensial, maka Indonesia pun tidak bisa mengabaikan keikutsertaannya sebagai anggota permanen dari G20 yang akan banyak menawarkan kesempatan dalam proses pengambilan kebijakan ekonomi dunia.

Terdapat dua hal yang mendasar yang ingin dicapai oleh Indonesia di forum G20, yakni meningkatkan standar mutu komoditas sesuai dengan tuntutan pasar internasional, agar mempunyai nilai kompetitif dengan produk-produk sejenis di pasar global (Stiftung, 2011). Dapat dipahami, karena Indonesia merupakan negara dengan sumber daya alam yang berlimpah, namun tidak diimbangi dengan kemampuan dalam pengolah dan pengelolaan yang tepat guna, sehingga menjadi sebuah peluang yang harus dimanfaatkan secara baik dengan akses yang lebih besar untuk memperoleh transfer teknologi dan ilmu pengetahuan dari sesame anggota forum G20, yang didominasi oleh negara besar yang berbasis industri padat modal. Poin fundamental kedua adalah forum G20 akan meningkatkan kapasistas Indonesia pada level internasional, posisi tawar negara akan semakin meningkat baik di berbagai arena negosiasi internasional, yang selama ini dinilai masih belum cukup kuat (Hermawan dkk, 2011). Pembuktian dari hal ini adalah usulan dari Indonesia terkait Global Expenditure Support Fund (GESF) yang diimplementasikan oleh IMF pada tahun 2008. Implikasi dari mekanisme GESF adalah bantuan likuiditas bagi banyak negara berkembang yang terkena dampak krisis keuangan global yang dapat dialokasikan untuk pembangunan infrastruktur dan pemulihan kondisi ekonomi domestik di banyak negara. Sehingga dapat dinilai bahwa ini sebuah capaian Indonesia untuk memberikan kontribusi positif untuk 
menyuarakan kepentingan negara diluar Forum G20. Meskipun mekanisme GESF ini pun telah banyak dikritik oleh kelompok yang pesimis melihat eksistensi IMF.

Akses pasar bebas menjadi sebuah hal yang harus bisa dimanfaatkan oleh Indonesia, namun sebagai sebuah negara hal ini pun perlu sebuah pengaturan yang cermat (Patunru dkk, 2018). Terkait dengan hal ini maka menjadi anggota tetap dalam forum G20 memberikan Indonesia akses yang lebih terbuka pada stimulasi ekonomi dunia. Berangkat dari pengalaman pasang surut situasi ekonomi yang telah dilalui oleh Indonesia tentunya akan membuat negara ini menjadi lebih cermat dalam merumuskan kerangka pemikiran bagi ekonomi dunia mealui forum G20. Terlebih ketika secara domestik Indonesia dihadapkan pada gejolak sentiment negatif terhadap keterbukaannya pada intervensi Bank Dunia dan IMF, yang dinilai telah memberikan paket program yang salah sasaran (Patunru dkk, 2018) sehingga menyebabkan semakin terpuruknya kondisi ekonomi domestik dalam kurun waktu tertentu. Isyu ini menjadi sebuah tolak ukur penting terkait keanggotaannya dalam forum G20, bahwa Indonesia akan dapat mempengaruhi pertimbangan dalam proses pengambilan putusan dari lembaga-lembaga dunia tersebut.

Putaran-putaran dari pertemuan WTO yang selalu dihadiri oleh Indonesia, yang seringkali harus menghadapi konflik antar negara terkait sengketa dagang, kebijakan pasar antara negara maju dan berkembang, serta mekanisme teknis dari perdagangan dunia. Sehingga menimbulkan kecurigaan dari banyak pihak terkait dari mandat yang dijalankan oleh WTO. Problematika perdagangan dunia ini sekaligus dapat dimanfaatkan oleh Indonesia di forum G20 untuk bisa menyuarakan kepentingan dari negara berkembang, yang selama ini banyak mengandalkan komoditas agraris dan komoditas padat karya lainnya untuk dapat memperoleh akses pasar yang lebih besar. Salah satu agenda penting yang kerap menjadi dialog yang intensif dalam setiap pertemuan Forum G20 adalah gagasan anti proteksionisme dengan mengusung ide liberasasi pasar dalam kegiatan perdagangan internasional. Indonesia pun sangat mendukung gagasan ini, karena hambatan perdagangan akan menghambat pertumbuhan ekonomi dunia, maka keniscayaan pasar harus tidak dibatasi dengan perilaku negara yang bersifat 
protektif (Stiftung, 2011). Meskipun akan menimbulkan pertanyaan baru, mampukah Indonesia berhadapan dengan kekuatan hegemoni dari beberapa negara yang selama ini mendominasi kegiatan perdagangan dunia? Seberapa besar pengaruh hasil pertemuan G20 tehadap WTO sebagai pemegang kendali perdagangan dunia?

Pesimisme ini akan menjadi terabaikan, ketika sebuah riset dilakukan oleh Lembaga Friedrich Ebert Stiftung bersama tim riset G20 dari Universitas Katolik Parahyangan pada tahun 2011, yang menemukan beberapa indikator terkait posisi Indonesia di forum G20 sebagai sebuah optimisme. Temuan pertama adalah Indonesia adalah salah satu negara berkembang yang dianggap sebagai emerging economy yang tidak dapat disepelekan dari angka perdagangannya. Kedua, sebagai negara nomor 4 dengan jumlah populasi terbesar di dunia, maka para pengamat ekonomi menilai hal ini menjadi pasar yang menjanjikan bagi terserapnya berbagai komoditas. Selanjutnya, posisi Indonesia diyakini dapat menjadi jembatan bagi distorsi antara barat dan Islam, mengingat Indonesia adalah negara dengan populasi muslim terbesar di dunia. Temuan keempat, Indonesia merupakan negara demokrasi baru yang dinilai sebagai sebuah langkah yang dapat memberikan kesuksesan secara domestic, hal ini akan menjadi suatu hal yang baik untuk mempengaruhi yang lain terkait prinsip demokrasi yang diusung. Dan yang terakhir adalah posisi strategis Indonesia di kawasan, dikaitkannya dengan aktualiasasi di ASEAN yang cukup intensif. Lima indikator menjadi sebuah pijakan yang cukup esensial bagi Indonesia untuk memaksimalkan kapasitasnya, guna memperkuat pengaruhnya dalam forum ini.

Hal penting lainnya yang perlu diingat adalah keanggotaan forum G20 yang sangat terbatas, tentunya akan mempermudah konsolidasi terhadap perumusan komitmen bersama. Jika dibandingkan dengan Perserikatan Bangsa-Bangsa yang mempunyai skala keanggotaan yang besar, sehingga seringkali menuai kritik terkait responnya yang sangat lambat menangani isyu internasional yang tengah berlangsung (stiftung, 2011). Menjadi sebuah keniscayaan bahwa dengan dibatasi jumlah keanggotaannya, meskipun terkesan eksklusif namun dalam proses 
perumusan kebijakannya akan lebih efektif dan efisien. Karakteristik keanggotaan inilah menjadi sebuah kesempatan yang bisa digunakan Indonesia untuk berperan aktif dalam setiap pertemuan yang dilakukan. Tanpa mengabaikan common goal dari forum ini, yakni menumbuhkan komitmen internasional yang mampu memberikan solusi nyata bagi problematika ekonomi dunia, dalam artian semua langkah yang dilakukan ditujukan untuk kepentingan bersama secara menyeluruh, baik bagi negara anggota dan bukan anggota. Terlepas dari semua hal optimis dari aktualisasi Indonesia di Forum G20, pesimisme yang disuarakan dari berbagai pandangan yang mengkritisi bahwa klub ekonomi ini hanyalah sebuah tren dalam jangka waktu tertentu, karena tidak ada sebuah rekomendasi yang bersifat mengikat secara legal. Sehingga pengingkaran bahkan pengabaian dari negara besar di G20 akan kerap terjadi dalam forum-forum multilateral yang lain.

\section{HEGEMONIC POWER SEBAGAI TANTANGAN KEANGGOTAAN INDONESIA DI G20}

Kapasitas negara yang berasal dari kekuatan ekonomi adalah salah satu penentu posisi tawar dalam negosiasi internasional. Hal utama yang menjadi indikator kekuatan ekonomi negara adalah angka gross domestic product (GDP) sebagai tolak ukur dalam mengkontrol proses berjalannya negosiasi dan juga menentukan respon yang diberikan oleh negara lain (Frost, 2009). GDP ini tidak hanya diukur dari tingkat pertumbuhan pembangunan semata, tapi yang lebih penting dilandaskan pada tingkat pendapatan per kapita di negara tersebut (Allouini, 2009). Maka menjadi jelas bahwa negara kuat akan ditunjukan dari tingginya perolehan pendapatan per kapitanya. Dalam konteks ekonomi politik, negara dalam berinteraksi dalam kegiatan yang bersifat transaksional tidak akan lepas untuk mengejar kepentingan nasionalnya, yakni mengakumulasi aset dan kekayaannya, yang tentunya akan berkontribusi pada perolehan per kapita negara tersebut. Dalam konstelasi G20, yang banyak mengadopsi sistem Bretton Wood, bahwa negara yang berkontribusi modal atau iuran kenggotaan yang besar, maka negara tersebut dapat menjadi sentral dalam setiap rekomendasi dan putusan yang dihasilkan (Salim, 2010) 
Amerika Serikat dalam hal ini masih mendominasi dalam setiap negosiasi internasional, dalam Forum G20 pun pengaruhnya masih signifikan, salah satunya disebabkan oleh kontribusi modal yang besar telah ditanamkan dalam berbagai organisasi dan forum multilateral. Hal inilah yang kemudian banyak kalangan menilai bahwa banyak organisasi dan forum multilateral mempunyai standar ganda, sangat tergantung pada konteks dan siapa aktor yang terlibat dalam negosiasi tersebut. Sedangkan untuk posisi Indonesia dalam Forum G20, jika dilihat dari indikator pendapatan per kapita maka menempati posisi kedua terendah setelah India (Salim, 2010), sedangkan apabila ditinjau dari skala ekonominya, maka Indonesia mempunyai posisi yang lebih baik dibandingkan dengan Afrika Selatan, Argentina, dan Saudi Arabia, bahkan melampaui Australia (Salim, 2010).

Tabel 1: Pemetaan Keanggotaan G20 berdasarkan GDP

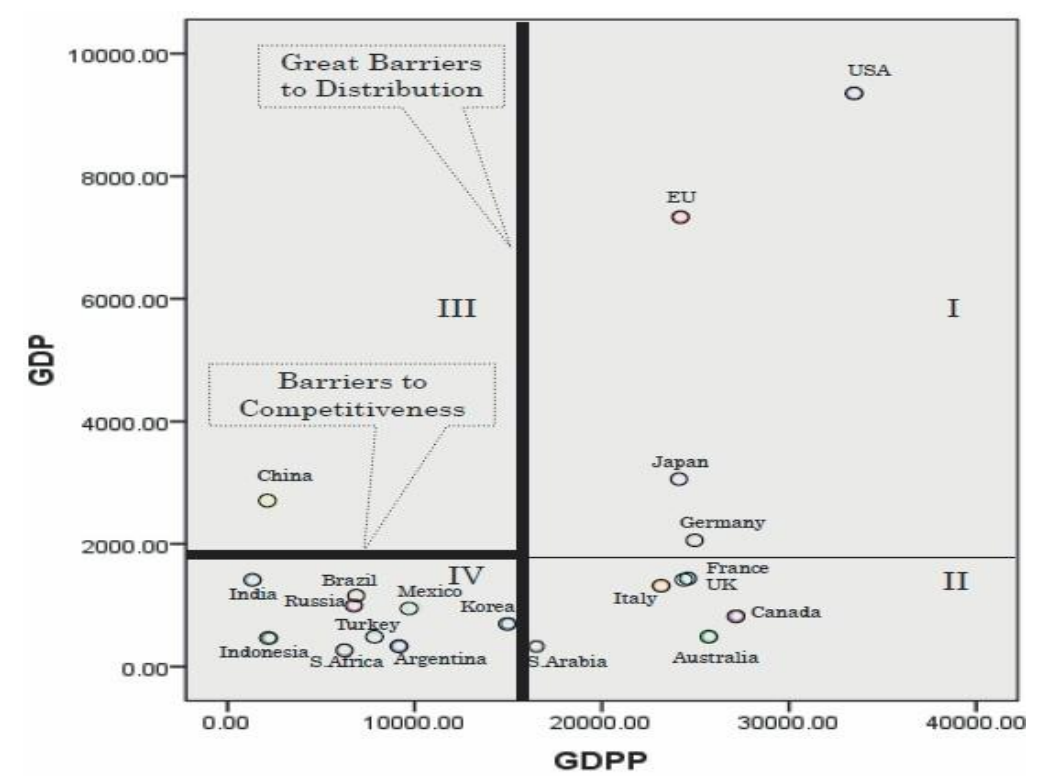

(sumber: Data GDP dari IMF World Economic Outlook, October 2009 (Salim, 2010))

Tabel tersebut menggambarkan pemetaan posisi Indonesia dalam forum G20, meskipun mempunyai posisi yang cukup baik jika dilihat dari skala GDP-nya dibandingkan dengan negara-negara berkembang lainnya yang berada dalam G20. Namun posisi tawar Indonesia belum cukup strategis untuk menyuarakan kepentingannya dalam sesi besar dalam KTT G20, meskipun demikian hal itu bisa terjembatani dengan menyatukan suara dengan sesama negara berkembang yang 
menjadi anggota forum tersebut. Jika dikritisi dari pemetaan tersebut, maka masih disangsikan kemampuan Indonesia untuk menyuarakan kepentingan negara berkembang diluar anggota G20, karena ia pun tentunya akan memprioritaskan kepentingannya dahulu yang harus berbagi alokasi suara dengan negara lainnya yang masuk dalam klasifikasi IV dari table tersebut.

Tantangan selanjutnya yang juga merupakan salah satu agenda penting dalam G20 yang telah dibahas sebelumnya, dan Indonesia pun termasuk negara anggota yang sangat mendukung gagasan ini, yakni anti proteksionisme dengan mengusung semangat liberalisasi pasar. Dalam hal ini Indonesia akan berhadapan dengan negara besar yang menjadi anggota forum G20. Masih banyak negara yang memainkan standar ganda ketika berhadapan dengan persoalan proteksionisme perdagangan. Dalam konteks keanggotaan negara-negara tersebut di WTO telah berkomitmen untuk berpartisipasi dalam liberalisasi pasar sebagai prinsip utama yang harus dipatuhi negara anggota WTO, seringkali secara implisit atau terangterangan masih banyak negara besar, terutama di Eropa dan Amerika Serikat, juga banyak negara di Asia melakukan kebijakan ekonomi domestik yang menimbulkan diskriminasi dalam praktik perdagangan internasional. Cina dan Jepang sebagai pusat kekuatan ekonomi di Asia sekaligus masuk dalam forum G20 pun melakukan proteksi terhadap produk strategis mereka. Praktik dumping yang diberlakukan sejak lama, meskipun telah dihapuskan tetapi praktiknya masih ada ketika mereka harus berhadapan dengan arus produk-produk kompetitif dari luar. Bahkan Paraguay dan Uruguay pun menerapkan pajak masuk yang tinggi untuk setiap barang impor yang akan masuk negara mereka (Stiftung, 2011). Sementara itu Uni Eropa mempunyai mekanisme General Scheme Preferences (GSP) yang memberikan perlakuan khusus terhadap komoditas tertentu dari negara yang yang sudah bersepakat dalam perjanjian tersebut. Dalam artian Uni Eropa tetap memberikan perlindungan bagi komoditas tertentu yang dihasilkan oleh negaranya, terutama produk pertanian. Hal yang sama pun diterapkan oleh Amerika Serikat dan Australia, sehingga jika melihat dari perilaku negara dalam konteks perdagangan, maka masih menjadi pekerjaan besar bagi Indonesia untuk dapat menjembatani problematika ini. 
Tumpang tindih kepentingan dan mandat yang melekat dari masing-masing negara anggota G20 yang juga secara aktif terlibat sebagai anggota tetap dalam WTO, membuat distorsi isyu perdagangan semakin tajam. Jika rekomendasi yang dihasilkan oleh G20 tidak bersifat mengikat, sedangkan semua putusan yang dihasilkan WTO mempunyai kekuatan legal yang harus dipatuhi sehingga putusan yang dihasilkan dalam setiap putaran WTO merupakan kebulatan suara atau aklamasi, maka hal ini menjadi saling bertolak belakang. Jika dikembalikan pada tujuan awal pembentukan G20 pada tahun 1999 adalah untuk merespon persoalan ekonomi dunia, serta membangun komitmen untuk menyelesaikan krisis global, maka ini menjadi sebuah jalan terjal yang sulit untuk dicapai karena semua rekomendasi yang diberikan bersfat himbauan. Indonesia tentunya bisa mencermati situasi ini dengan baik, karena apabila ia cukup frontal dalam merespon perilaku negara besar, maka harus juga bersiap untuk diasingkan dari pergaulan internasional, sebagai bentuk konsekuensi politis yang harus dihadapi.

Dalam WTO sendiri posisi negara berkembang dalam mekanisme pemberian suara dinilai masih dimarginalisasi (Odell, 2006). Sehingga untuk menyuarakan kepentingannya, negara berkembang termasuk Indonesia harus membentuk sebuah aliansi, yang terkadang dalam kelompok-kelompok kecil tersebut sering terdapat free rider yang seringkali berseberangan kepentingan ketika sekutu mereka dinilai tidak menguntungkan(Salim, 2010). Meskipun pada kenyataannya pasca perang dingin kekuatan di hegemoni negara besar, khususnya Amerika Serikat telah melemah, dimana banyak negara lebih cenderung memilih mekanisme multilateral dalam perdagangan, hal itu tidak menyurutkan bentuk praktik diskriminasi dalam perdagangan (Oatley, 2006). Hal yang sama pun dilakukan Indonesia untuk meningkatkan aka perdagangannya dengan aktif di WTO dan mekanisme regional. Namun dua mekanisme perdagangan, baik itu multilateral (WTO) dan regional adalah dua hal yang sama penting sebagai satu kesatuan. Negara akan menaruh mandatnya pada WTO selama organisasi ini mampu merefleksikan kepentingannya (Oatley, 2006), sehingga ketika rekomendasi datang dari luar termasuk yang berasal dari Forum G20 dan dinilai 
tidak strategis bagi negara-negara besar di WTO, oleh karena itu pengaruh yang simultan dari forum lain kepada WTO tidaklah mudah untuk dilakukan.

Penjelasan diatas telah direfleksikan sejak lama oleh paradigma realisma bahwa prinsip utama dari negara adalah mempertahankan keberlangsungan hidupnya dengan cara-cara tertentu, termasuk kerjasama dan memberi bantuan pada pihak lain (Donelly, 2004). Meskipun pada saat ini dominasi negara secara unilateral bukan lagi sebagai metode yang strategis, sehingga mekanisme multilateral dimanfaatkan oleh negara untuk mengejar kepentingan nasionalnya (Masoed, 1998). Sehingga paham realisma dan tingkah laku negara dalam praktik ekonomi bisa saling melengkapi, terutama korelasinya yang kuat dengan salah satu paradigma dalam ekonomi politik internasional, yakni merkantilisme (neomerkantilisme). Lebih jauh lagi jika melihat eksistensi dari forum G20 dapat dibangun sebuah pandangan kritis bahwa negara-negara anggota tetap akan merefleksikan kepentingan nasionalnya masing-masing sebagai sebuah hakikat yang utama.

Banyak pihak yang kemudian mempertanyakan dari itikad negara G20 dalam menangani persoalan ekonomi global, karena diantara anggota forum tersebut pun masih banyak menyisakan persoalan yang belum terselesaikan. Contohnya kasus perang dagang antara Cina dan Amerika Serikat, yang direspon oleh salah satu pihak dengan bea masuk produk baja. Bahkan dalam mekanisme legal formal melalui dispute-settlement body (DSB) yang diinisiasi oleh WTO, masih belum menghasilkan solusi yang tepat. Diperparah dengan standar ganda yang kerap melekat pada WTO, maka dari itu perbaikan dari segi transparansi dari mekanisme DSB harus segera dilakukan (Goodman dalam CSIS, 2019) Problematika kemudian memunculkan kritik yang pesimis terkait peran Indonesia di G20 hanya sebagai sebuah tren semata. Meskipun Indonesia adalah satu-satunya negara ASEAN yang masuk dalam mekanisme G20, namun jika dilihat secara nyata skala pertumbuhan ekonominya masih tertinggal dibandingkan dengan Singapura dan Malaysia (Stiftung, 2011). Ditambah dengan persoalan domestik di Indonesia, yakni tingginya indeks korupsi yang terjadi berdampak pada proses birokrasi, 
menambah kesangsian akan kemampuannya dalam menyuarakan kepentingan nasional, terlebih kepentingan negara berkembang lainnya. Selain itu belum tercapainya target pertumbuhan ekonomi yang telah direncanakan sebelumnya, capaian di semester pertama pada tahun 2010 hanya 400 triliyun rupiah dari yang direncanakan sebesar 1.894 triliyun rupiah (Stiftung, 2011).

Indonesia masih harus melalui proses panjang dan berliku untuk memberikan pembuktian bahwa dirinya memang layak untuk menjadi bagian dari klub ekonomi eksklusif, G20. Meskipun Indonesia masih tertinggal pendapatan perkapitanya dibandingkan dengan negara ASEAN lainnya, yakni Malaysia dan Singapura, namun secara populasi lebih unggul ketimbang kedua negara tersebut. Salah satu modal mendasar yang dapat dimanfaatkan oleh Indonesia. Hingga tahun 2045 Indonesia dapat memanfaatkan bonus demografi ini untuk menghasilkan angka usia produktif hingga 200 juta, yang tentunya diimbangi dengan kualitas yang mumpuni (Arieza dalam CNN Indonesia, 2019). Sumber daya manusia yang produktif dan unggul sebagai modal untuk menggerakan roda perekonomian pada sentimen pasar yang positif. Sehingga Indonesia tidak dianggap hanya mengikuti tren semata dengan menjadi anggota G20.

\section{KESIMPULAN}

Keanggotaan Indonesia dalam forum G20 adalah sebuah langkah besar bagi capaian Indonesia yang harus disikapi secara cermat. Indonesia mempunyai kesempatan dan ruang yang lebih untuk merefleksikan kepentingan nasionalnya, sekaligus menyuarakan kepentingan dari negara berkembang lainnya di luar forum tersebut. Pasang surut atas ketidakpastian ekonomi global saat ini harus mampu ditangani oleh Indonesia secara baik. Peluang yang ditawarkan dalam forum ini harus dapat dimanfaat secara baik oleh Indonesia, karena menjadi bagian dari penentu arah dan reformasi birokrasi berbagai lembaga ekonomi dunia. Keberpihakan Indonesia terhadap kesenjangan ekonomi negara berkembang dengan negara maju akan memberikan sebuah harapan baru bagi tata ekonomi global. Optimisme terhadap fragmentasi pandangan antara barat dan Islam bisa terakomodasi dengan masuknya Indonesia dalam G20, yang akan memberikan 
dampak positif bagi geliat pertumbuhan ekonomi dunia. Terlepas dari pandangan pro dan kontra, Indonesia akan terus melangkah maju untuk beraktualisasi dalam proses pertumbuhan ekonomi dunia.

\section{Referensi}

Alouini, Olfa. 2009. Country Size, Economic Performace and The Political Economy of the Euro Zone: An Empirical Study of The Size Divide. Paris: $\mathrm{N}^{\circ}$ 2009-01 MARS 2009 COLLECTION OFCE/ANR Nº7 (tersedia di: http://citeseerx.ist.psu.edu/viewdoc/download?doi=10.1.1.850.6175\&rep=r ep1\&type=pdf). Diakses pada tanggal 7 Juli 2019

Arieza, Ulfa. 2019. Melihat 'Taji' Indonesia di Antara Negara Raksasa G-20. (tersedia di: https://www.cnnindonesia.com/ekonomi/20190628134408532-407329/melihat-taji-indonesia-di-antara-negara-raksasa-g20). Diakses pada tanggal 7 Juli 2019

Donelly, Jack. 2004. Realism and International Relations. United Kingdom: Cambridge University Press

Frost, Ellen L. 2009. What is Economic Power? In The Global Redistribution of Economic Power. Joint Force Quaterly. Issue 53, $2^{\text {nd }}$ quarter 2009

Goodman Mathew P. 2019. G-20 Osaka: Inside and Out (tersedia di: https://www.csis.org/analysis/g20-osaka-inside-and-out). Diakses pada tanggal 4 Juli 2019

Hermawan P. Yulius, dkk. 2011. G-20 Research Project: The Role of Indonesia in the G-20: Background, Role, Objectives of Indonesia Membership. Jakarta: Friedrich-Ebert-Stiftung

Mas'oed, Mohtar. 1998. Perspektif EKonomi Politik dalam Studi Hubungan Internasional. Yogyakarta: Bahan Matrikulasi Program Pasca Sarjana Ilmu Politik Konsentrasi Hubungan Internasional, Universitas Gadjah Mada

Nowzad, Bahram. 1981. Essay in International Finance: The IMF and Its Critics. New Jersey: Princeton University. No. 146

Oatley. Thomas. 2006. International Political Economy: Interest and Institutions in The Global Economy. United States: Pearson Education, Inc. $2^{\text {nd }}$ edition

Odell, John S. 2006. Negotiating Trade: Developing Countries in The WTO and NAFTA. New York: Cambridge University Press. $1^{\text {st }}$ edition 
Patunru A. Arianto, Mari Pangestu, M. Chatib Basri. 2018. Indonesia in The New World: Globalisation, Nationalism, and Sovereignty. Singapore: ISEAS Publishing. $1^{\text {st }}$ edition

Salim, Zamroni. 2010. Indonesia in the G-20: Benefits and Challenges Amidst National Interest and Priorities. (tersedia di: https://www.researchgate.net/publication/233885641_Indonesia_in_the_G 20_Benefits_And_Challenges_Amidst_National_Interests_and_Priorities). Diakses pada tanggal 4 Juli 2019 